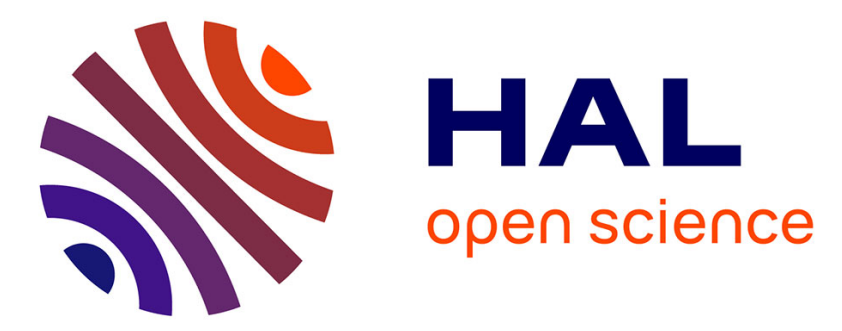

\title{
Phytoseiid mites (Acari: Phytoseiidae) of apple and almond trees in regions of western and south-western
} Iran

\author{
B. Asali Fayaz, M. Khanjani, F. Molavi, E.A. Ueckermann
}

\section{To cite this version:}

B. Asali Fayaz, M. Khanjani, F. Molavi, E.A. Ueckermann. Phytoseiid mites (Acari: Phytoseiidae) of apple and almond trees in regions of western and south-western Iran. Acarologia, 2011, 51 (3), pp.371-379. 10.1051/acarologia/20112020 . hal-01600108

\section{HAL Id: hal-01600108 https://hal.science/hal-01600108}

Submitted on 2 Oct 2017

HAL is a multi-disciplinary open access archive for the deposit and dissemination of scientific research documents, whether they are published or not. The documents may come from teaching and research institutions in France or abroad, or from public or private research centers.
L'archive ouverte pluridisciplinaire HAL, est destinée au dépôt et à la diffusion de documents scientifiques de niveau recherche, publiés ou non, émanant des établissements d'enseignement et de recherche français ou étrangers, des laboratoires publics ou privés.

\section{(ㅇ)(1) $\$$}

Distributed under a Creative Commons Attribution - NonCommercial - NoDerivatives $\mid 4.0$ 


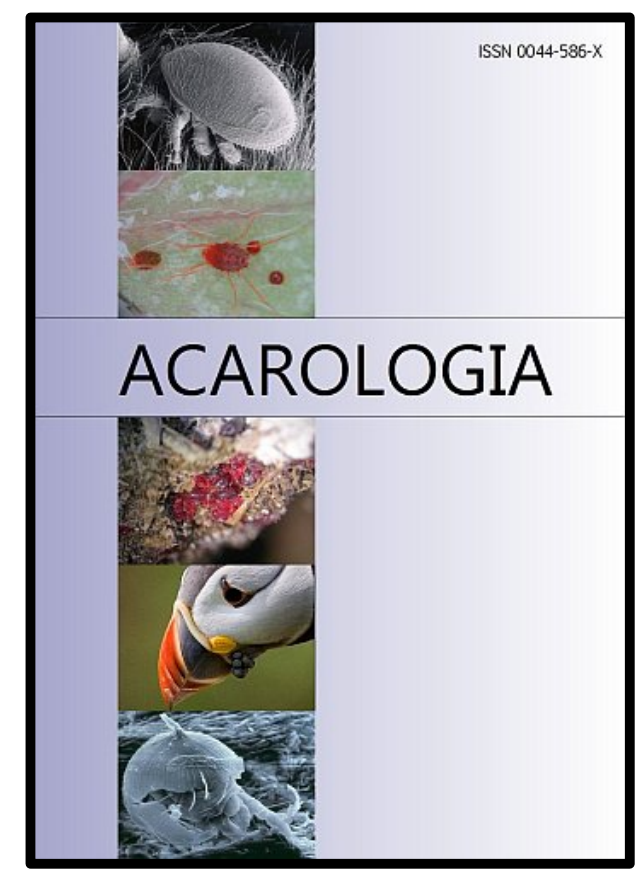

\section{ACAROLOGIA}

A quarterly journal of acarology, since 1959

Publishing on all aspects of the Acari

All information:

http://www1.montpellier.inra.fr/CBGP/acarologia/ acarologia@supagro.inra.fr

\section{OPEN ACCESS}

\section{Acarologia is proudly non-profit, with no page charges and free open access}

Please help us maintain this system by encouraging your institutes to subscribe to the print version of the journal and by sending us your high quality research on the Acari.

Subscriptions: Year 2017 (Volume 57): $380 €$ http://www1.montpellier.inra.fr/CBGP/acarologia/subscribe.php

Previous volumes (2010-2015): $250 € /$ year (4 issues)

Acarologia, CBGP, CS 30016, 34988 MONTFERRIER-sur-LEZ Cedex, France

The digitalization of Acarologia papers prior to 2000 was supported by Agropolis Fondation under the reference ID 1500-024 through the « Investissements d'avenir » programme

(Labex Agro: ANR-10-LABX-0001-01)
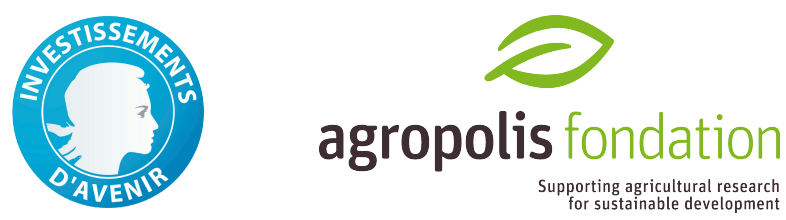

Acarologia is under free license and distributed under the terms of the

Creative Commons-BY-NC-ND which permits unrestricted non-commercial use, distribution, and reproduction in any medium, provided the original author and source are credited. 


\title{
PHYTOSEIID MITES (ACARI: PHYTOSEIIDAE) OF APPLE AND ALMOND TREES IN REGIONS OF WESTERN AND SOUTH-WESTERN IRAN
}

\author{
Bahman ASAli FAYAZ ${ }^{1}$, Mohammad KHANJANi ${ }^{1,{ }^{*},}$, Fatemeh MOLAVI ${ }^{1}$, \\ Edward A. UECKERMANN ${ }^{2,3}$ \\ (Received 28 February 2011; accepted 09 May 2011; published online 23 September 2011) \\ ${ }^{1}$ Department of Plant Protection, College of Agriculture, Bu Ali-Sina University, Hamadan, I. R. Iran. \\ mkhanjani@gmail.com ( ${ }^{*}$ corresponding author); basalifayaz@gmail.com \\ ${ }^{2}$ ARC-Plant Protection Research Institute, Private Bag X134, Queenswood, Pretoria, 0121 South Africa. UeckermannE@arc.agric.za \\ ${ }^{3}$ School of Environmental Sciences and Development, North-West University, Potchefstroom Campus 2520, South Africa
}

\begin{abstract}
Eight phytoseiid species belonging to three genera were collected in apple and almond orchards from the Provinces of Hamedan, Kurdistan and Chahar Mahal va Bakhtiari, in western and south-western Iran. Typhlodromus (Anthoseius) bagdasarjani Wainstein and Arutunjan, 1967 was the most abundant species, being collected from both plant species in the three provinces.
\end{abstract}

KEYWORDS - Acari; predatory mites; Phytoseiidae; apple; almond; Iran

\section{INTRODUCTION}

In the western and south-western areas of Iran, apples, Malus domestica L. (Rosacea), are cultivated on more than 2,000 ha, with a total production of over 153,000 t, whereas almonds, Prunus dulcis (Mill.) D. A. Webb (Rosaceae), are cultivated on almost 14,000 ha with a total production of almost 13,000 $t$ (Anonymous, 2009). Members of the phytophagous mite families Eriophyidae and Tetranychidae are important pests of those crops in Iranian orchards (Khanjani and Hadad Irani Nejad, 2006). Species of the mite family Phytoseiidae are important predators of eriophyids and tetranychids. More than 20 phytoseiid species are commercially reared for use as biological control agents of mites and small insects harmful to greenhouse and field crops worldwide (Chant and McMurtry, 2007; Gerson et al.,
2003). Moraes et al. (2004) mentioned 39 phytoseiid species described and recorded from apple trees but none from almonds. Daneshvar and Denmark (1982) described T. (A.) iranensis and Ueckermann et al. (2009) redescribed Typhlodromus (Anthoseius) khosrovensis Arutunjan from apple trees in northwest Iran. In this study, the results of a survey conducted in apple and almond orchards during 20082010 in 3 provinces in western and south-western Iran are given.

\section{MATERIALS AND METHODS}

This study was carried out in 8 commercial apple orchards in the Provinces of Hamedan and Kurdistan and in 7 commercial almond orchards in the Province of Chahar Mahale va Bakhtiari, in 2008- 
2010. Phytoseiid mites were collected by beating or shaking shoots over a white tray or by extracting them from samples of soil and fallen fruits in Berlese funnels. The mites were preserved in $70 \%$ ethanol and then mounted on slides in Hoyer's medium (Walter and Krantz, 2009) for later examination under a Nomarski Interference Contrast Olympus microscope.

All measurements are given in micrometers with the means followed by the respective ranges in parentheses. A key to the species found in this survey is given. The classification systems used follows that of Chant and McMurtry (2007). The dorsal and ventral setal nomenclature is that of Rowell et al. (1978) and Chant and Yoshida-Shaul (1991). Idiosomal setal patterns are given according to Chant and Yoshida-Shaul (1992). All specimens are deposited in the Collection of the Acarology Laboratory, University of Bu-Ali Sina, Hamedan, Iran.

\section{RESULTS}

\section{Typhlodrominae}

\section{Typhlodromus (Anthoseius) bagdasarjani Wainstein and Arutunjan}

Typhlodromus bagdasarjani Wainstein and Arutunjan, 1967: 1765 Typhlodromus (Anthoseius) bagdasarjani, Moraes et al., 2004: 311

Remarks - Measurements of setae agree with those included in the original description of this species.

\section{Female}

Dorsum - Dorsal setal pattern: 12A:8A. Tectum convex, $30(26-33)$ wide. Dorsal shield reticulated, 362 (355-368) long, width at the widest level of podonotal region of the dorsal shield 174 (173 175); five pairs of solenostomes. Measurements of dorsal setae as follows: j1 $25(24-25)$, j3 32 (31 - 33), j4 20 (19-20), j5 19 (18 - 19), j6 22 (21 - 23), J2 28 (26 - 30), J5 $11(10-11)$, z2 $23(20-25)$, z3 28 (27 - 28), z4 29 (28 - 30), z5 19 (18 - 20), Z4 54 (52 - 55), Z5 69 $(65-73)$; s4 32 (28 - 35); s6 38 (35 - 40), S2 40 (35 45); S4 37 (33 - 40); S5 30 (27 - 33); r3 31 (28 - 33);
R1 27 (24 - 30). All setae smooth, except Z4 and Z5, serrated.

Venter - Setae set on venter of gnathosoma of the following lengths: h1 23 (22 - 23), h2 21 (20 $21)$, h3 18 (16 - 20) and palp coxal seta 26 (25 - 26). Length of tritosternum 90 - 93 (92). Sternal shield smooth and with two pairs of setae (St1 and St2) and two pairs of lyrifissures; setae St 3 and St 4 each set on separated platelets. Length of sternal setae as follows: St1 33 (29 - 35), St2 31 (28 - 33), St3 31 (28 31), St4 30 (28 - 31), St5 $27(23-31)$. Genital shield $113(110-115)$ long and $75(72-78)$ at the widest level. Ventrianal shield without pre-anal pores and with a few transverse lines, $110-120$ long and $80-$ 90 wide at level setae ZV2. Setae JV5 50 (48 - 53).

Chelicera - Movable digit 25, toothless; fixed digit 27, with four teeth and a pilus dentilis.

Peritreme - Extending to level between setae z3-4, 106 (100 - 112) long.

Spermatheca - Calyx 14 (11 - 17) long and 10 (9 - 10) wide, bell-shaped.

Legs - Length of legs I-IV as follows: leg I 305 (301 - 308), leg II 264 (261 - 267), leg III 265 (263 266) and leg IV 351 (347 - 355). Basitarsus IV with one knobbed macroseta (St) $48(45-49)$.

Specimens examined - Hamedan Province Heydareh village $\left(34^{\circ} 48^{\prime}, \mathrm{N} ; 48^{\circ} 28^{\prime} \mathrm{E}\right)$, Hamedan (Apr. 2009) (n=2), Hamedan (Oct. 2009) $(\mathrm{n}=$ 1), Ghorveh Dar Jazin (Oct. 2009) $(\mathrm{n}=4)$, Kurdistan Province - Kamyaran vicinity (Nov. 2009) ( $\mathrm{n}=$ 4), Chenu village, (Nov. 2009) $(n=2)$. All on apple trees. Chahar Mahal va Bakhtiari Province Emamieh (32 32' 11" N; 50 $8^{\prime} 50^{\prime \prime}$ E) (Jul. and Oct. 2009), Hureh (Jul. 2008); Cham Heidar (32 30'40" $\mathrm{N} ; 51^{\circ} 00^{\prime} 27^{\prime \prime} \mathrm{E}$ ) (Sept. 2009) infested with eriophyid

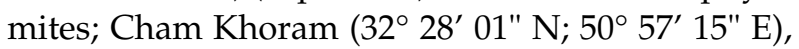
(Aug. and Sept. 2009); Shoorab (32 $29^{\prime} 23^{\prime \prime} \mathrm{N} ; 50^{\circ}$ 57’ 03" E) (Jul. 2009) Cham Ali (32 $30^{\prime} 40^{\prime \prime} \mathrm{N} ; 50^{\circ} 53^{\prime}$

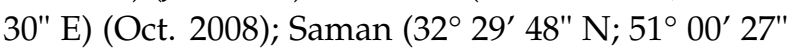
E) (Jul. 2009). All on almond trees $(n=31)$.

\section{Typhlodromus (Anthoseius) iranensis (Denmark and Daneshvar)}

Amblydromella iranensis Denmark and Daneshvar in Daneshvar and Denmark, 1982: 8 Typhlodromus (An- 
thoseius) iranensis, Moraes et al., 2004: 332

Note - This species is suspected to be junior synonym of T. ( A.) kazachstanicus Wainstein, 1958 (Faraji et. al., 2007).

Remarks - Measurements of setae agree with those included in the original description of this species.

\section{Female}

Dorsum — Dorsal setal pattern: 12A:8A. Tectum convex, $32(30-34)$ wide. Dorsal shield reticulated, 370 (370) long, width at the widest level of podonotal region of the dorsal shield 171 (166 - 175); three pairs of solenostomes. Length of dorsal setae as follows: j1 21 (20 - 21), j3 31 (30 - 31), j4 20 (19-20), j5 $21(20-21)$, j6 $24(23-24), \mathrm{J} 228(27-28), \mathrm{J} 54$ (3 4), z2 27 (26 - 27), z3 29 (28 - 30), z4 31 (30 - 31), z5 21 (20 - 21), Z4 48 (46 - 49), Z5 59 (57 - 60); s4 32 (31 - 32); s6 36 (33 - 38), S2 40 (38 - 41); S4 36 (35 - 38); S5 29 (27 - 30); r3 31 (30 - 31); R1 32 (30 - 33). All dorsal setae smooth, except Z4 and Z5, serrated.

Venter - Setae set on venter of gnathosoma of the following lengths: h1 25 (24-25), h2 25 (24-25), h3 $23(20-25)$ and palp coxal seta $29(28-30)$. Tritosternum bifid and 94 (92 - 95) long; Sternal shield smooth and with two pairs of setae (St1 and St2) and two pairs of lyrifissures; setae St 3 and St 4 each set on separated platelets. Length of sternal setae as follows: St1 31 (30 - 32), St2 31 (30 - 31), St3 34 (33 35), St4 31 (30-31), St5 33 (31-34). Genital shield 140 (140) long; 75 (75 - 79) at the widest level. Ventrianal shield with a few transverse lines, 121 (116 125) long and $81(80-82)$ wide at level of setae ZV2; no pre-anal pores. Setae JV5 50 (50).

Chelicera - Movable digit $28(27-28)$, with one tooth; fixed digit $29(28-30)$, with three teeth and a pilus dentilis.

Peritreme - Apex of peritreme reaches level between setae $\mathrm{s} 4$ and $\mathrm{z} 4$.

Spermatheca - Calyx $17(15$ - 18) and 13 (10 15) wide, fundibular; atrium nodular.

Legs - Length of legs I-IV as follow: leg I 313 (300 - 325), leg II 260 (260), leg III 274 (267 - 280) and leg IV 354 (345 - 363). Basitarsus IV with one knobbed macroseta (St) $53(51$ - 54).

Specimens examined - Hamedan Province Qorveh Dar Jazin, Razan vicinity (35 $21^{\prime} \mathrm{N}$; $49^{\circ} 06^{\prime}$ E), (Oct. 2009), $(n=2)$, on apple trees.

\section{Typhlodromus (Anthoseius) khosrovensis Arutunjan}

Typhlodromus khosrovensis Arutunjan, 1971: 306 Typhlodromus (Anthoseius) khosrovensis, Moraes et al., 2004 : 333 Redescription: Ueckermann et al., 2009

Remarks - The specimens examined are very similar to the original description of the species.

\section{Female}

Dorsum - Dorsal setal pattern: 12A:8A. Tectum convex, 32 (31 - 33) wide. Dorsal shield reticulated, $334(330-338)$ and width at the widest level of podonotal region of the dorsal shield 158 (155 160); four pairs of solenostomes. Length of dorsal setae as follows: j1 $22(21-23), \mathrm{j} 331(30-31), \mathrm{j} 419$ $(18$ - 19), j5 20 (19 - 20), j6 24 (22 - 25) , J2 26 (25 27), J5 4 (3 - 4), z2 24 (23 - 24), z3 30 (29 - 30), z4 29 (29), z5 20 (19 - 20), Z4 41 (39 - 42), Z5 55 (51 - 59); s4 33 (32 - 34); s6 36 (35 - 36), S2 38 (35 - 40); S4 33 (32 - 33); S5 17 (15 - 19); r3 28 (27 - 28); R1 29 (28 30). Setae smooth except $Z 4$ and $Z 5$, serrated.

Venter - Setae set on venter of gnathosoma of the following lengths: h1 $22(21$ - 22), h2 21 (18 - 23), h3 $22(20$ - 23) and palp coxal seta 26 (24 27). Tritosternum bifid, 79 (75 - 82) long; Sternal shield smooth with two pairs of setae (St1 and St2) and two pairs of lyrifissures; posterior margin with a median lobe; setae St3 and St4 each set on separated platelets. Length of sternal setae as follows: St1 29 (27 - 30), St2 30 (30), St3 29 (27 - 31), St4 27 (25 - 28), St5 27 (25 - 28). Genital shield 120 (118 121) long and 70 (70) wide at level of setae St5. Ventrianal shield with a few transverse lines, 112 (107117) long and 80 (80) wide at level of ZV2, with no pre-anal pores. Setae (JV5) 49 (48 - 50).

Chelicera - Movable cheliceral digit 26 (25-26), with one tooth; fixed digit $27(26-27)$, with four teeth and a pilus dentilis. 
Peritreme - Apex of peritreme extending to level of $\mathrm{z} 4$.

Spermatheca - Calyx $12(11$ - 13) long and 9 (8 -9) wide, cup or bell-shaped; atrium incorporated in calyx.

Legs - Length of legs as follows: Leg I 305 (300 - 310), leg II 260 (255 - 265), leg III 257 (255 - 260) and leg IV 234 (230 - 237). Basitarsus IV with a knobbed macroseta (St) 51 (50 - 51).

Specimens examined - Hamedan Province Heidareh village $\left(34^{\circ} 48^{\prime}, \mathrm{N} ; 48^{\circ} 28^{\prime} \mathrm{E}\right)$, Hamedan, (Sept. 2009) $(n=3)$, on apple trees $(n=3)$.

\section{Paraseiulus talbii (Athias-Henriot)}

Typhlodromus talbii Athias-Henriot, 1960: 75 Paraseiulus talbii, Abbasova, 1972: 11; Moraes et al., 2004: 301

Remarks - The specimens examined are very similar to the original description of the species.

\section{Female}

Dorsum - Dorsal setal pattern: 13A: 9A. Tectum convex, 30 (26 - 33) wide. Dorsal shield reticulated, 381 (367 - 395) long; width at the widest level of podonotal region of the dorsal shield 203 (203); three pairs of solenostomes. Length of dorsal setae as follows: j1 $20(17-23)$, j3 29 (28 - 30), j4 27 (26 27), j5 29 (28 - 29), j6 35 (33 - 37), J2 38 (37 - 38), J5 12 (12), z2 32 (30 - 33), z3 34 (32 - 36), z4 36 (36), z5 28 (27 - 28), z6 31 (31), Z3 39 (38 - 40), Z4 43 (42 - 43), Z5 45 (44 - 45), s4 44 (43 - 45); s6 35 (34 - 35), S2 41 $(40-42) ;$ S4 36 (35 - 36), S5 40 (39 - 40); r3 32 (30 34); R1 34 (33-35). All dorsal setae smooth, except Z4 and Z5, serrated.

Venter - Setae set on venter of gnathosoma of the following lengths: h1 20 (20), h2 21 (20 - 21), h3 16 (15 - 16) and palp coxal seta 26 (25 - 26). Tritosternum bifid and 79 (79) long; Sternal shield smooth and with two pairs of setae (St1 and St2) and 2 pairs of lyrifissures; setae St3 set on unsclerotized cuticle and setae St 4 setae on platelets. Length of sternal setae St1 $29(28-30)$, St2 $27(26-28)$, St3 $29(28-30)$, St4 $29(28-29)$, St5 $29(28-29)$. Genital shield 150 (150) long and 68 (68) wide at level of setae St5. Ventrianal shield with a few transverse lines, 140 (140) long, and 62 (62) at level of anal opening, with no pre-anal pores and two pairs of pre-anal setae JV1 26 (25 - 26), ZV2 28 (27 - 28), one pair of para-anal seta 20 (20), post anal setae 17 (17). Seta JV5 $47(45-48)$.

Peritreme - Apex of peritreme extending to level between setae j3-z2.

Spermatheca - Calyx 16 (15 - 17) long, 10 (8 11) wide and saccular.

Legs - Length of legs I-IV as follows: leg I 353 (350 - 355), leg II 273 (270 - 275), leg III 281 (279 282) and leg IV 373 (365 - 380). Basitarsus IV with one macroseta (St) $31(30-31)$.

Specimens examined - Chahar Mahal va Bakhtiari Province - Cham Khoram (32 28' 01" N; $50^{\circ} 57^{\prime} 15^{\prime \prime}$ E) (Agu. 2009), Cham Heidar (32³0'40" N; 51 00’27" E) (Sept. 2009) and Saman (Jul. 2008). All seven specimens were collected from foliage of almond trees infested with Tetranychus urticae Koch and eriophyid mites.

\section{AMBLYSEIINAE}

\section{Neoseiulus agrestis (Karg)}

Typhlodromus agrestis Karg, 1960: 449 Neoseiulus agrestis, Moraes et al., 2004: 98

Remarks - The specimens examined are very similar to the original description of the species.

\section{Female}

Dorsum - Dorsal setal pattern: 10A: 9B. Tectum convex, 40 (40) wide. Dorsal shield reticulated and $368(360-375)$ long, width at the widest level of podonotal region of the dorsal shield 193 (190 195); four pairs of solenostomes. Measurements of dorsal setae as follows: j1 14 (12 - 15); j3 20 (19 - 21); j4 18 (17 - 18); j5 18 (17 - 18); j6 21 (20 - 22), J2 24 (23 - 25); J5 13 (12 - 13); z2 18 (17 - 18); z4 21 (20 - 22); z5 18 (17 - 18); Z1 21 (18 - 23), Z4 25 (24 - 26), Z5 37 (34 - 40); s4 24 (23 - 25); S2 23 (22 - 23); S4 26 (24 - 27); S5 21 (21); r3 21 (20 - 21); R1 21 (20 - 21). All dorsal setae smooth.

Venter - Setae set on venter of gnathosoma of the following lengths: h1 25 (24-25), h2 24 (23-24), 
h3 $25(24-25)$ and palp coxa setae $26(25-27)$. Tritosternum bifid and $89(88-90)$ long; Sternal shield smooth and with three pairs of setae (St1, St2 and St3) and two pairs of lyrifissures. Lengths of sternal setae as follows: St1 $28(27-28)$, St2 $25(24-25)$, St3 23 (22 - 24), St4 $26(25$ - 26), St5 $24(22-26)$. Sternal setae with two pairs of lyrifissures. Genital shield $123(120$ - 125) long; $74(70$ - 78) wide at level of setae St5. Ventrianal shield with a few transverse lines, $130(128$ - 131) long, and $99(98$ - 100) wide at level of setae ZV2, with a pair of pre-anal pores posteromedially to seta JV2. Setae JV5 34 (33 - 35).

Chelicera - Movable digit 30, with one tooth; fixed digit $34(32-35)$ three teeth and a pilus dentilis.

Peritreme - Apex of peritreme extending to level seta j1.

Spermatheca - Calyx $29(27$ - 30) long and 13 $(12-13)$ wide, tubular and flaring towards vesicle.

Legs - Length of legs I-IV as follows: leg I 355 (350 - 360), leg II 259 (258 - 260), leg III 244 (238 250) and leg IV 253 (345 - 360). Basitarsus IV with one pointed macroseta (St) 51 (50 - 51).

Specimens examined - Hamedan Province Moeejin village, Marianaj vicinity, (Apr. 2010) $(\mathrm{n}=2)$, on apple trees.

\section{Neoseiulus bicaudus (Wainstein)}

Amblyseius bicaudus Wainstein, 1962: 146 Neoseiulus bicaudus, Congdon, 2002: 23; Moraes et al., 2004: 108

Remarks - The specimens examined are very similar to the original description of the species. However, 7 pairs of solenostomes are observed on the dorsal shield of the specimens examined but only 6 pairs are mentioned in the original description.

\section{Female}

Dorsum — Dorsal setal pattern: 10A: 9B. Tectum convex, $44(43-44)$ wide. Dorsal shield reticulated, 404 (398 - 410) long; width at the widest level of podonotal region of the dorsal shield $193(185-200)$ at level of setae R1; seven pairs of solenostomes. Length of setae as follows: j1 $22(21-23)$, j3 32 (30
- 33), j4 $16(14-17)$, j5 $16(15-16)$, j6 18 (16 - 20), J2 17 (16 - 18), J5 14 (13 - 15), z2 27 (25 - 30), z4 21 (21 - 22), z5 16 (16), Z1 $22(20-24)$, Z4 $41(40-42)$, Z5 85 (80 - 89), s4 34 (33 - 35), S2 35 (34 - 36), S4 37 (36 - 38), S5 42 (40 - 44); r3 33 (30 - 35); R1 30 (29 - 31), both of setae $\mathrm{r} 3$ and R1 on soft integument. All dorsal setae smooth except S4, S5, Z4 and Z5, serrated.

Venter - Setae set on venter of gnathosoma of the following lengths: h1 $22(21-23), \mathrm{h} 221$ (20 22), h3 $23(21-25)$ and palp coxal seta $27(26-27)$. Length of tritosternum 93 (92-94). Sternal shield reticulated, bears three pairs of setae (St1, St2 and St3) and two pairs of lyrifissures. Length of sternal setae St1 $27(24-30)$, St2 $25(23-26)$, St3 24 (22 25), St4 $28(26-30)$, St5 $23(20-25)$. Seta St4 set on platelet. Genital shield 124 (123 - 125) long and $81(75-87)$ at level of St5. Ventrianal shield reticulated, 135 (130 - 140) long, $106(105-107)$ wide at level of setae ZV2, one pair of pre-anal pores posterior to JV2 and distance between their bases 41 (41), three pairs of pre-anal setae JV1 16 (14 - 18), ZV2 21 $(20-21)$ and JV2 $17(15-19)$, one pair of para-anal setae $18(17-18)$, post anal seta $21(20-21)$. Seta JV5 54 (53 - 55), serrated.

Chelicera - Movable digit 33 (30 - 35), with one tooth; fixed digit $37(35-40)$ long, with six teeth and a pilus dentilis.

Peritreme - Apex of peritreme extending to level between setae $\mathrm{j} 1$ and $\mathrm{j} 3$.

Spermatheca - Calyx $11(9-12)$ long and 9 (7 10) wide, bowl-shaped with short neck between the latter and the nodular atrium.

Legs - Length of legs I-IV as follows: leg I 350 (340 - 360), leg II 271 (263 - 280), leg III 277 (265 290) and leg IV 355 (345-360). Basitarsus IV with a pointed macroseta, $75(71-78)$ long.

Specimens examined - Chahar Mahal va Bakhtiari province - Cham Khoram $\left(32^{\circ} 28^{\prime} 01^{\prime \prime} \mathrm{N}\right.$ $50^{\circ} 57^{\prime} 15^{\prime \prime}$ E) (Jun. 2010) (n = 2), Saman ( $32^{\circ} 30^{\prime} 40^{\prime \prime}$ $\left.\mathrm{N} 51^{\circ} 00^{\prime} 27^{\prime \prime} \mathrm{E}\right)$ (Oct. 2008) (n=1), Cham Heidar $\left(32^{\circ} 30^{\prime} 0 " \mathrm{~N} 50^{\circ} 53^{\prime} 51^{\prime \prime} \mathrm{E}\right)$ (Aug. 2009) $(\mathrm{n}=2)$ ). All on almond trees. 


\section{Neoseiulus sugonjaevi (Wainstein and Abbasova)}

Amblyseius sugonjaevi Wainstein and Abbasova, 1974: 796 Neoseiulus sugonjaevi, Moraes et al., 2004: 145

Remarks - The specimens examined are very similar to the original description of the species.

\section{Female}

Dorsum - Dorsal setal pattern: 10A: 9B. Tectum convex, 38 (36 - 40) wide. Dorsal shield reticulated, 359 (355 - 363) long; width at the widest level of podonotal region of the dorsal shield 184 (170 198); three pairs of solenostomes. Length of setae as follows: j1 20 (19 - 20), j3 26 (25 - 27), j4 20 (20), j5 20 (20), j6 20 (19 - 20), J2 26 (25 - 27), J5 12 (11 - 12), z2 23 (22 - 23), z4 26 (26), z5 21 (20 - 21), Z1 25 (25), Z4 32 (31 - 32), Z5 43 (42 - 43); s4 28 (28); S2 26 (25 - 27); S4 26 (25 - 26); S5 23 (21 - 25); r3 21 (21); R1 22 (21 22). All dorsal setae smooth, except $Z 5$, serrated.

Venter - Setae set on venter of gnathosoma of the following lengths: h1 23 (21 - 25), h2 23 (20 - 25), h3 $24(22-25)$ and palp coxal seta $26(25-26)$. Tritosternum 88 (86 - 90) long; Sternal shield smooth and with three pairs of setae (St1, St2 and St3) and two pairs of lyrifissures. Length of sternal setae St1 27 (26 - 28), St2 26 (24 - 27), St3 26 (26), St4 26 (24 27), St5 25 (23 - 27). Genital shield 113 (112 - 115) long and $75(74-75)$ wide at level of setae St5. Ventrianal shield with longitudinal lines, 123 (115 - 130) long and 103 (100 - 106) wide at level of setae ZV2; with a pair of pre-anal pores at posterior of setae JV2. Seta JV5 39 (37 - 40).

Chelicera - Movable digit $31(30-33)$, with one tooth; fixed digit 35, with four teeth and a pilus dentilis.

Peritreme - Apex of peritreme extending to level of seta $\mathrm{j} 1$.

Spermatheca - Calyx $22(20$ - 23) long and 9 (7 -10) wide, distal half of calyx slightly bulged and proximal half flared.

Legs - Length of legs I-IV as follows: leg I 335 (325 - 345), leg II 248 (240 - 255), leg III 250 (240 260) and leg IV 351 (341 - 360). Basitarsus IV with one pointed macroseta (St) $59(56-62)$ and genu IV with one pointed macroseta (Sge) 25 (25).

Specimens examined - Hamedan Province Pole Shekasteh region, between Toyserkan and Asad Abad vicinities, (Oct. 2009) $(n=2)$. Kurdistan Province - Naran village, Sanandaj, (Nov. 2009) $(\mathrm{n}=1)$ and Chenu village, Sanandaj, (Nov. 2009) $(\mathrm{n}=1)$. All from soil and litter under apple tree.

\section{Neoseiulus zwoelferi (Dosse)}

Typhlodromus zwoelferi Dosse, 1957: 301 Neoseiulus zwoelferi, Moraes et al., 2004: 152.

Remarks - The specimens examined are very similar to the original description of the species.

\section{Female}

Dorsum — Dorsal setal pattern: 10A: 9B.Tectum convex, $43(40-45)$ wide. Dorsal shield reticulated $408(400-415)$ long, width at the widest level of podonotal region of the dorsal shield 209 (207 $210)$; seven pairs of solenostomes. Length of dorsal setae as follows: j1 $20(19-20)$, j3 $26(25-26)$, j4 18 (18), j5 18 (18), j6 21 (21), J2 24 (22 - 25), J5 11 (10 11), z2 25 (24 - 25), z4 21 (20 - 21), z5 19 (19), Z1 23 (22 - 23), Z4 35 (33 - 36), Z5 50 (49 - 50); s4 31 (30 32); S2 28 (26 - 30); S4 25 (24 - 25); S5 24 (24); r3 24 (24); R1 25 (25). All dorsal setae smooth, except Z5, serrated.

Venter - Setae set on venter of gnathosoma of the following lengths: h1 26 (25 - 26), h2 26 (25 - 27), h3 $26(24-27)$ and palp coxal seta $30(29-30)$. Tritosternum with two lacinia, 97 (95 - 98) long; Sternal shield smooth and with three pairs of setae (St1, St2 and St3) and two pairs of lyrifissures; setae St4 set on platelets. Length of sternal setae St1 35 (35), St2 30 (30), St3 30 (29 - 31), St4 33 (33), St5 30 (28 $31)$. Genital shield $127(120-135)$ long and 83 (80$85)$ wide at level of setae St5. Ventrianal shield with a few transverse lines, $141(138$ - 143) long and 116 (112 - 120) wide at level of setae ZV2; one pair of pre-anal pores posterior to setae JV2. Setae JV5 47 $(43-50)$.

Chelicera - Movable digit 32 (31 - 33) long, toothless, fixed digit 35 , with four teeth and a pilus dentilis. 


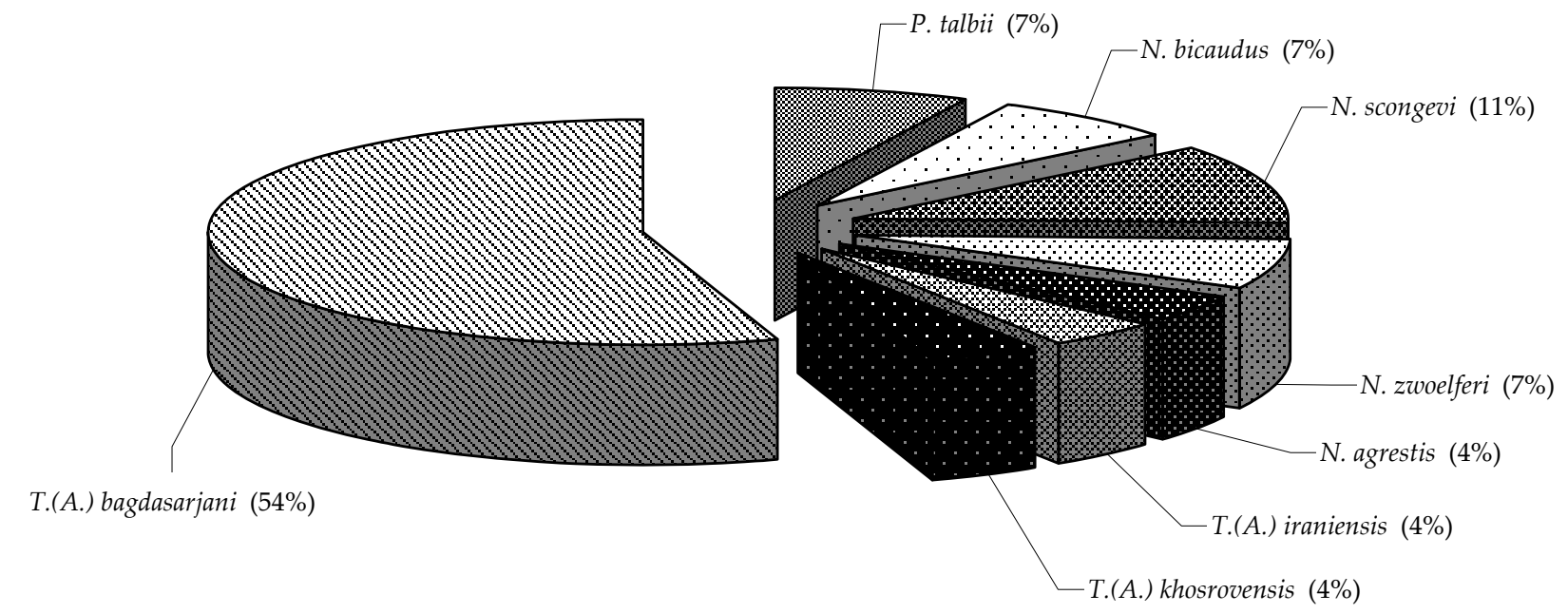

FIGURE 1: Relative abundance of specimens of phytoseiid mites from apple and almond orchards in the Hamedan, Kurdistan and Chahar Mahale va Bakhtiari Provinces of Iran, based on samples collected in 2008-2010.

Peritreme - Apex of peritreme extending to near seta $\mathrm{j} 1$.

Spermatheca - Calyx $22(21-23)$ long and 14 $(12-15)$ wide, with a slender neck that flares towards vesicle.

Legs - Length of legs I-IV as follows: leg I 299 (286 - 290), leg II 299 (295 - 303), leg III 296 (292 300) and leg IV 418 (415 - 420). Basitarsus IV with one pointed macroseta (St) 71 (66 - 75); genu IV also with one pointed macroseta (Sge) 31 (30 - 31).

Specimens examined - Hamedan Province Heydareh village $\left(34^{\circ} 48^{\prime}, \mathrm{N} ; 48^{\circ} 28^{\prime} \mathrm{E}\right)$, Hamedan, (Nov. 2009) $(n=1)$, from soil and litter under apple trees. Kurdistan Province - Chenu village, Sanandaj, (Nov. 2009) $(n=4)$, from apple trees $(n=5)$.

\section{Key to phytoseiid species found in this survey (females).}

1. Setae z3 and s6 absent (AmblyseiinaeNeoseiulus)............................ 2

- Both setae z3 and s6 present (Typhlodrominae)................................. 5

2. Seta Z5 longer than $80 \mu \mathrm{m} . \ldots \ldots \ldots \ldots \ldots \ldots$ . N. bicaudus Wainstein, 1962

— Seta Z5 shorter than $80 \mu \mathrm{m} . . . . . . . . . . . . . .3$
3. Dorsal shield with 7 pairs of solenostomes ...... .N. zwoelferi Dosse, 1957

— Dorsal shield with 3-4 pairs of solenostomes...4

4. Dorsal shield with 3 pairs of solenostomes ...... .N. sugonjaevi Wainstein and Abbasova, 1974 - Dorsal shield with 4 pairs solenostomes... .N. agrestis Karg, 1960

5. Dorsal setae z6 and Z3 present

Paraseiulus talbii Athias-Henriot 1960

. Dorsal setae z6 and Z3 absent ............... 6

6. Movable digit of chelicera without tooth and 5 pairs of solenostomes on dorsal shield ............ ...T.(A.) bagdasarjani Wainstein and Arutunjan, 1967 - Movable digit of chelicera with 1 tooth and 3-4 pairs of solenostomes on dorsal shield.......... 7

7. Dorsal shield with 3 pairs of solenostomes and

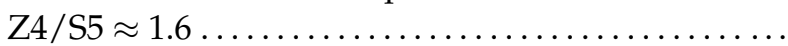
...T.(A.) iraniensis Denmark and Daneshvar, 1982 - Dorsal shield with 4 pairs of solenostomes and $\mathrm{Z} 4 / \mathrm{S} 5 \approx 2.4 \ldots .$. T.(A.) khosrovensis Arutunjan, 1971 


\section{DISCUSSION}

This survey showed that Typhlodromus (Anthoseius) bagdasarjani was the dominant of the eight species collected in apple and almond orchards in the three provinces (Figure 1). The following step will be to evaluate these predators specially the dominant species for its effectiveness against important pest mite species of the families Tetranychidae and Eriophyidae in Iran. The aim is to reduce chemical control.

\section{ACKNOWLEDGEMENTS}

We wish to thank Prof G. J. De Moraes (Depto. Entomologia, Fitopatologia e Zoologia Agrícola, Universidade de São Paulo/ Escola Superior de Agricultura "Luiz de Queiroz", 13418-900 Piracicaba-SP, Brazil) for suppling us with literature.

\section{REFERENCES}

Abbasova E.D. 1972 - Phytoseiid mites (Parasitiformes: Phytoseiidae) of Azerbaijan - Avtoreferat Dissertatsii na Soiskanie Uchenoy Stepeni Kandidata Biologicheskikh Nauk - Akadrmiya Nauk Azerbaydzhanskoy SSR, Institut Zoologii, Baku, Azerbaijan, 34 pp. [in Russian].

Anonymous. 2009 - The result of sampling design of Horticultural productions of Iran - Ministry of Agricultural Jahad: Publisher. pp. 95. [In Persian]

Arutunjan E.S. 1971 - New species of the genus Typhlodromus Scheuten, 1857 (Parasitiformes, Phytoseiidae) - Dokl. Akad. Nauk. Armyanskoi SSR, Armenia, 52: 305-308 [in Russian].

Athias-Henriot C. 1960 - Phytoseiidae et Aceosejidae (Acarina: Gamasina) d' Algérie. IV. Genre Typhlodromus Scheuten, 1857 - Bull. Soc. Hist. Nat. Afrique du Nord, 51: 62-107.

Chant D.A., McMurtry J.A. 2007 - Illustrated keys and diagnoses for the genera and subgenera of the Phytoseiidae of the world (Acari: Mesostigmata) - Indira Publishing House, West Bloomfield, Michigan, USA. pp. 220.

Chant D.A., Yoshida-Shaul E. 1991 - Adult ventral setal patterns in the family Phytoseiidae (Acari: Gamasina) — Int. J. Acarol, USA. 17: 187-199.

Chant D.A., Yoshida-Shaul E. 1992 - Adult idiosomal setal patterns in the family Phytoseiidae (Acari: Gamasidae) — Int. J. Acarol., 18: 177-193.
Congdon B.D. 2002 - The family Phytoseiidae (Acari) in western Washington State with descriptions of three new species — Int. J. Acarol., USA, 28(1): 3-27.

Daneshvar H., Denmark H.A. 1982 - Phytoseiids of Iran (Acarina: Phytoseiidae) — Int. J. Acarol., USA, 8: 3-14.

Dosse G. 1957 - Morphologie und biologie von Typhlodromus zwoelferi n. sp. (Acar.,Phytoseiidae) - Z. Angew. Entomol., Germany, 41(2-3): 301-311.

Faraji F., Hajizadeh J., Ueckermann E.A. Kamali, K., McMurtry J.A. 2007 - Two new records for Iranian phytoseiid mites with synonymy and keys to the species of Typhloseiulus Chant and McMurtry and Phytoseiidae in Iran (Acari: Mesostigmata) - Int. J. Acarol., 33: 231-239.

Gerson U., Smiley R. L., Ochoa R. 2003 - Mites (Acari) for Pest Control - Blackwell Science Ltd: Publisher, UK. pp. 539.

Karg W. 1960 - Zur Kenntnis der Typhlodromiden (Acarina: Parasitiformes) aus Ackerund Grunlandboden —Z. Angew. Entomol., Germany, 47: 440-452.

Khanjani M., Hadad Irani Nejad K. 2006 - Injurious mites of Agricultural crops in Iran - Bu-Ali Sina Unversity: Publisher. pp. 515. [In persian].

Moraes G.J. De., McMurtry J.A., Denmark H., Campos C.B. $2004-$ A revised catalog of the mite family Phytoseiidae - Zootaxa. 434:1-494.

Rowell H.J., Chant D.A., Hansell R.I.C. 1978 - The determination of setal homologies and setal patterns on the dorsal shield in the family Phytoseiidae (Acarina: Mesostigmata) - Can. Entomol., 110: 859-876.

Ueckermann E.A., Jalaeian M., Saboori A., Seyedoslami H. 2009 - Re-description of Typhlodromus (Anthoseius) khosrovensis Arutunjan, first record for Iran (Acari: Phytoseiidae) - Acarologia, XLIX, 1-2: 23-27.

Wainstein B.A. 1958 - New species of mites of the genus Typhlodromus (Parasitiformes: Phytoseiidae) from Georgia - Soobshcheniya Akad. Nauk Gruzinskoy SSR, 21(2): 201-207 [in Russian].

Wainstein B.A. 1962 - Some new predatory mites of the family Phytoseiidae (Parasitiformes) of the USSR fauna - Entomologicheskoe Obozrenie, Russia, 41, 230-240 [in Russian]; Entomol. Rev., Russia, 41: 139146 [English translation].

Wainstein B.A., Abbasova E. D. 1974 - Two new species of the genus Amblyseius (Parasitiformes: Phytoseiidae) from Azerbaijan [in Russian] — Zool. Zh., Russia, 53: 796-798.

Wainstein B.A., Arutunjan E.S. 1967 - New species of predaceous mites of the genera Typhlodromus Scheuten and Paraseiulus Muma (Parasitiformes, Phytoseiidae) [in Russian] — Zool. Zh., Russia, 46: 1764-1770. 
Walter D., Krantz G. W. 2009 - Collection, rearing and preparing specimens. In: Krantz G.W., Walter D. [Eds.]. A Manual of Acarology. 3rd ed. - Oregon State University Book Stores, Inc., Corvallis, Oregon. 83-96.

\section{COPYRIGHT}

(cc) EY-No-ND Asali Fayaz et al.. Acarologia is under free license. This open-access article is distributed under the terms of the Creative Commons-BY-NC-ND which permits unrestricted non-commercial use, distribution, and reproduction in any medium, provided the original author and source are credited. 